\title{
PENGARUH LAMA PENYIMPANAN DAUN SALAM KOJA (Murraya koenigii (L) Spreng) TERHADAP TOTAL FENOL DAN AKTIVITAS ANTIBAKTERI PADA PERTUMBUHAN Salmonella enteritidis ATCC 13067
}

\author{
The Storage Duration on Total Phenols and Antibacterial Activity of Curry Leaves (Murraya \\ koenigii (L) Spreng) Against the Growth of Salmonella Enteritidis ATCC 13067 \\ ${ }^{1}$ Berilin Abigail Jonathan, ${ }^{2}$ Gusti Ayu Ekawati*, ${ }^{2}$ Ni Made Indri Hapsari A. \\ ${ }^{1)}$ Mahasiswa Program Studi Ilmu dan Teknologi Pangan, Fakultas Teknologi Pertanian, Unud \\ ${ }^{2}$ Dosen Program Studi Ilmu dan Teknologi Pangan, Fakultas Teknologi Pertanian, Unud \\ Kampus Bukit Jimbaran, Badung - Bali
}

\begin{abstract}
This study aims to determine the effect of storage duration of curry leaves (Murraya koenigii (L) Spreng) on the total phenols and antibacterial activity of Salmonella enteritidis ATCC 13067, and the appropriate storage duration of curry leaves to produce the highest total phenols and the antibacterial activity. This study used a Completely Randomized Design (CRD) with treatment duration of storage that is $0,3,6,9$, and 12 days. The treatment was repeated 3 times to produced 15 experimental units. Data were analyzed by analysis of variance (ANOVA), if each treatment had a difference then preceded with the Duncan Test. The observed variables were total phenols and antibaterial activity S. enteritidis ATCC 13067. Qualitative testing showed that curry leaves extract positively containing phenols. The storage duration of curry leaves significantly affected the total phenols and antibaterial activity of $S$. enteritidis ATCC 13067. The best treatment was produced in the treatment without storage with the highest total phenols was $3,598.17 \mathrm{mg} / 100 \mathrm{~g}$ and the highest antibaterial activity power was $-1,321$ log cycles or $95.16 \%$ mortality bacteria.
\end{abstract}

Keywords: Storage duration, curry leaves, total phenol, Salmonella enteritidis, contact method

\section{PENDAHULUAN}

Salmonella merupakan bakteri yang paling umum menyebabkan penyakit keracunan makanan di negara berkembang. Penyakit yang disebabkan oleh Salmonella disebut salmonellosis. Salmonellosis atau gastroenteritis dibagi menjadi dua grup besar yaitu non-typhoid salmonellosis atau gastroenteritis dan typhoid salmonellosis atau demam enteric. Pada gastroenteritis infeksi bakteri terbatas pada epitelium usus sedangkan pada demam enterik infeksi bakteri terjadi pada keseluruhan sistem (Del-Portillo, 2000). Pada tahun 2016 di Indonesia jumlah penderita diare atau gastroenteritis yang dilayani di sarana kesehatan sebanyak 3.176.079 penderita dan terjadi peningkatan pada tahun 2017 yaitu menjadi 4.274 .790 penderita atau $60,4 \%$ dari perkiraan diare di sarana kesehatan (Anon., 2018). Pengobatan penyakit gastroenteritis dapat diobati dengan mengkonsumsi antibiotik kimia atau antibiotik alami, namun antibiotik kimia mempunyai efek samping yang memiliki resiko lebih besar dibandingkan antibiotik alami. Maka dari itu antibiotik alami mulai digalakkan agar masyarakat tidak mengkonsumsi antibiotik kimia secara terus-menerus. Antibiotik alami atau antibakteri terdapat dalam tumbuhtumbuhan sebagai bentuk pertahanan diri dari pemangsanya. Tumbuhan yang mengandung antibakteri adalah daun kemangi, daun sembukan, daun salam, daun gaharu, daun kersen, daun juwet, daunt alas, dan daun salam koja.

Daun salam koja (Murraya koenigii (L) Spreng) merupakan salah satu daun yang sering digunakan sebagai bahan penyedap masakan, khususnya masakan khas Aceh karena dapat memberikan aroma dan rasa yang khas. Menurut penelitian Choudhory dan Garg (2007); serta Sudarwanto dkk., (2015), daun salam koja secara kualitatif memiliki kandungan saponin, terpenoid, karbazol alkaloid, glikosida, flavonoid, tanin, fenol, dan antioksidan seperti

*Korespondensi Penulis:

E-mail: ayuekawati@unud.ac.id 
tokoferol, $\beta$-karoten, dan lutein. Senyawa fenol berperan sebagai antioksidan, antiinflamasi, dan antibakteri. Antibakteri adalah senyawa yang digunakan untuk mengendalikan pertumbuhan bakteri yang bersifat merugikan. Menurut penelitian Sudarwanto dkk., (2015), ekstrak daun salam koja dapat menghambat pertumbuhan Staphylococcus aureus, Eschericia coli, dan Pseudomonas sp. Fenol merupakan salah satu senyawa yang berperan sebagai antibakteri. Aktivitas antibakteri senyawa fenolik disebabkan kemampuannya merusak lipid pada membran plasma mikroorganisme sehingga menyebabkan isi sel keluar. Fenol dapat merusak dinding sel dan membran sel, menkoagulasi protein, merusak ATPase, merusak sulfohidril dari protein, dan merusak DNA sehingga efektif memhambat bakteri (Siswandono dan Soekardjo, 1995; Fazlara dan Ekhtelat, 2012).

Fenol dapat dianalisis dengan metode ekstraksi. Salah satu metode ekstraksi yang tidak membutuhkan alat yang banyak dan biayanya yang rendah adalah maserasi. Maserasi adalah proses ekstraksi menggunakan pelarut dengan beberapa kali pengadukan pada suhu ruangan. Prosedurnya dilakukan dengan merendam bahan dalam pelarut yang sesuai dalam wadah tertutup. Cairan penyari akan menembus dinding sel dan masuk ke dalam rongga sel yang mengandung zat aktif, zat aktif akan larut karena adanya perbedaan konsentrasi antara larutan zat aktif di dalam sel dengan yang di luar sel, maka larutan yang terpekat didesak keluar. Peristiwa tersebut terjadi berulang-ulang sehingga terjadi keseimbangan konsentrasi antara larutan di luar sel dan di dalam sel. Dasar pemilihan pelarut adalah menyesuaikan pelarut dengan senyawa yang akan dianalisis mempunyai kepolaritasan yang sama. Pelarut polar mudah mengekstrak senyawa yang bersifat polar, begitu pula sebaliknya pelarut non polar mudah mengekstrak senyawa yang bersifat non polar. Fenol memiliki sifat polar, sehingga salah satu pelarut adalah aquades. Aquades biasanya digunakan untuk mengekstraksi produk tumbuhan dengan aktivitas antimikroba (Tiwari dkk., 2011). Pelarut ini merupakan pelarut yang mudah didapat, murah, bersifat netral dan tidak berbahaya sehingga aman jika digunakan dalam bahan pangan.

Pada umumnya, masyarakat menyimpan daun salam koja di dalam suatu ruangan. Daun salam koja sangat cepat layu dan aromanya berkurang seiring lamanya waktu penyimpanan. Dari berbagai penelitian diketahui bahwa ada beberapa golongan senyawa fenol yang sensitif terhadap suhu panas dan hal ini dapat menyebabkan senyawa fenol tersebut mengalami degradasi selama proses pemanasan ataupun selama waktu penyimpanan (Mrmosanin dkk, 2015). Penurunan fenol kemungkinan menyebabkan aktivitas antibakteri juga menurun. Maka dari itu diperlukan adanya penelitian mengenai lama penyimpanan daun salam koja terhadap total fenol dan aktivitas antibakteri terhadap pertumbuhan Salmonella enteritidis ATCC 13067 dan lama waktu penyimpanan daun salam koja yang tepat untuk menghasilkan total fenol dan aktivitas antibakteri pertumbuhan Salmonella enteritidis ATCC 13067 tertinggi.

\section{METODE PENELITIAN}

\section{Tempat dan Waktu}

Penelitian dilaksanakan di Laboratorium Analisis Pangan dan Laboratorium Mikrobiologi di Gedung Agrokomplek lantai III Fakultas Teknologi Pertanian Universitas Udayana, serta Laboratorium Forensik Kepolisisan Daerah Bali, Kerobakan - Denpasar Barat. Penelitian ini dilaksanakan dari bulan April hingga September 2019.

\section{Bahan dan Alat}

Bahan yang digunakan dalam penelitian ini adalah daun salam koja tua yang berwarna hijau tua yang dipetik 9 hingga 10 helai daun di setiap tangkainya yang diperoleh di Jl. Siulan - Denpasar, $\mathrm{FeCl}_{3}$, reagen Folin-Ciocalteu, $\mathrm{Na}_{2} \mathrm{CO}_{3}$, isolat bakteri Salmonella enteritidis ATCC 13067 diperoleh dari PT. Seafood Inspection Laboratory - Denpasar, aquades steril, etanol $96 \%, \mathrm{H}_{2} \mathrm{SO}_{4}, \mathrm{H}_{2} \mathrm{O}_{2}, \quad \mathrm{LB}$ 
(Lactose Broth), gliserol 30\%, alkohol 95\%, alkohol 70\%, SSA (SalmonellaShigella Agar), spiritus, NA (Nutrient Agar), larutan $\mathrm{NaCl}$ 0,9\%, karbol Kristal ungu, lugol, safranin, dan $\mathrm{BaCl}_{2} 1 \%$.

Alat - alat yang digunakan dalam penelitian ini adalah pisau, talenan, aluminium foil, kapas, kain kasa steril, evaporator, water bath, nampan plastik, buret, air es, wadah, spektrofotometer, pipet $10 \mathrm{ml}$, kertas saring Whatman no. 1, corong plastik, toples, wadah maserasi, labu ukur (Pyrex), batang pengaduk, batang bengkok, timbangan analitik, mikropipet, freezer, inkubator (Memmert), tip, laminar flow cabinet (Kojair), bunsen, vortex, mikroskop, cawan petri (Pyrex), jarum ose, tabung reaksi (Pyrex), gelas beker (Pyrex), erlenmeyer (Pyrex), gelas ukur (Pyrex), tabung mikrovial, dan tabung effendorf.

\section{Rancangan Penelitian}

Rancangan percobaan yang digunakan pada penelitian ini menggunakan Rancangan Acak Lengkap (RAL) dengan perlakuan penyimpanan daun salam koja pada suhu ruang yang terdiri dari 5 taraf, yaitu: penyimpanan hari ke-0, penyimpanan hari ke-3, penyimpanan hari ke-6, penyimpanan hari ke-9, dan penyimpanan hari ke-12. Masing-masing perlakuan diulang sebanyak 3 kali sehingga diperoleh 15 unit percobaan. Data hasil analisis diuji dengan analisis sidik ragam (ANOVA), apabila masing-masing perlakuan terdapat perbedaan maka dilanjutkan dengan Uji Duncan.

\section{Pelaksanaan Penelitian Penyimpanan Daun Salam Koja}

Daun yang digunakan adalah daun tua berwarna hijau tua yang dipetik 9 hingga 10 helai daun di setiap tangkainya. Daun salam koja disortasi dengan tujuan memisahkan benda asing dari daun. Daun salam koja selanjutnya ditimbang sebanyak 200 gram untuk masing-masing perlakuan. Daun dengan perlakuan P1 yaitu hari penyimpanan ke-0 langsung dilakukan proses ekstraksi, sedangkan untuk perlakuan daun salam koja yang lain ditaruh pada nampan dan ditempatkan di atas meja kemudian disimpan selama 12 hari di suatu ruangan..

\section{Pembuatan Ekstrak Daun Salam Koja}

Daun salam koja yang telah disimpan sesuai dengan perlakuan diekstrak dengan cara dimaserasi. Daun salam koja dicuci dengan air mengalir, kemudian ditiriskan dengan cara diangin-anginkan. Daun ditimbang sebanyak 50 gram lalu dipotongpotong hingga ukuran daun mencapai $0,3-$ $0,5 \mathrm{~cm}$. Selanjutnya ditempatkan dalam suatu wadah dan ditambah aquades sebanyak $950 \mathrm{ml}$ agar seluruh daun dapat terendam dengan baik lalu diaduk hingga homogen. Proses maserasi dilakukan selama 72 jam, setelah 72 jam dilakukan proses penyaringan dengan kain satin steril dan dilanjutkan dengan penyaringan menggunakan kertas Whatman no. 1. Filtrat dievaporasi dengan suhu $60^{\circ} \mathrm{C}$ dengan kecepatan 100 rpm selama 2 jam dan didapatkan hasil ekstrak pekat daun salam koja. (Widnyani, 2014 yang telah dimodifikasi). Ekstrak daun salam koja yang telah didapat dilanjutkan dengan pengujian total fenol dan aktivitas antibakteri pada Salmonella enteritidis ATCC 13067.

\section{Variabel yang Diamati}

Variabel yang diamati adalah total fenol secara kualitatif (Harborne, 1987) dan secara kuantitatif (Chun dkk., 2003), konfirmasi bakteri Salmonella enteritidis ATCC 13067, dan jumlah koloni bakteri $S$. enteritidis ATCC 13067 yang dapat dihambat oleh ekstrak daun salam koja dengan menggunakan metode kontak (Parhusip dkk., 2008 yang telah dimodifikasi).

\section{Uji Total Fenol \\ Secara Kualitatif}

Pengujian fenol secara kualitatif diuji dengan cara mengambil beberapa tetes sampel dimasukkan ke dalam tabung reaksi kemudian ditetesi dengan larutan $\mathrm{FeCl}_{3}$, kemudian diamati perubahan warna pada sampel. Sampel menunjukkan perubahan warna biru kehitaman pada sampel 
menunjukkan adanya fenol pada sampel (Harborne, 1987).

\section{Secara Kuantitatif}

Reagen Folin-Ciocalteu didilusi dengan air 1:9 (v/v). Ke dalam 1,25 ml reagen ditambahkan $50 \mu \mathrm{l}$ sampel, diinkubasi selama 2 menit pada suhu ruang kemudian ditambahkan $1 \mathrm{ml}$ sodium karbonat $(75 \mathrm{~g} / \mathrm{L})$. selanjutnya diinkubasi selama 15 menit pada suhu $50^{\circ} \mathrm{C}$ dan didinginkan dengan cepat dalam wadah yang berisi air es. Absorbansi dibaca pada panjang gelombang $760 \mathrm{~nm}$ dalam 15 menit. Hasil pembacaan dibandingkan dengan kurva standar menggunakan asam galat (Chun dkk., 2003).

\section{Uji Konfirmasi Bakteri}

Uji konfirmasi pada bakteri Salmonella enteritidis ATCC 13067 dilakukan 3 uji yaitu:

1. Pengamatan bentuk koloni

Pengamatan bentuk koloni dilakukan dengan cara mengamati hasil koloni S. enteritidis ATCC 13067 pada mikroskop perbesaran 100x.

2. Pewarnaan Gram

Tahap awal yaitu isolat bakteri yang telah disegarkan diratakan pada kaca objek yang sudah dibersihkan dan difiksasi $\pm 20 \mathrm{~cm}$ di atas api Bunsen. Preparat ditetesi dengan pewarna kristal violet lalu didiamkan selama kurang lebih 1 menit, kemudian dibilas dengan air mengalir dengan posisi preparat dimiringkan dan larutan lugol lalu didiamkan selama 2 menit kemudian kembali dibilas dan dikeringkan. Preparat kembali ditetesi dengan etanol $96 \%$ lalu didiamkan selama $\pm 10-20$ detik kemudian kembali dibilas dan dikeringkan. Terakhir preparat ditetesi dengan safranin dan didiamkan $10-20$ detik, kemudian dibilas dan dikeringkan seperti hal sebelumnya, lalu preparat diamati dibawah mikroskop dengan pembesaran 100x. Hasil yang didapati dari pengujian Salmonella enteritidis ATCC 13067 menunjukkan warna merah karena tergolong ke dalam bakteri Gram negatif (Juniarhati, 2011).

3. Uji Katalase

Uji Katalase dilakukan menurut Harrigan dan McCance (1998). Isolat bakteri diambil satu ose, kemudian dioleskan pada kaca preparat. Kaca preparat ditetesi dengan larutan $\mathrm{H}_{2} \mathrm{O}_{2}$ $3 \%$. Hasil pengujian positif ditandai dengan terbentuknya gelembung gas pada preparat, sedangkan hasil pengujian negatif ditandai dengan tidak terbentuknya gelembung gas pada preparat.

\section{Uji Aktivitas Antibakteri Ekstrak Daun Salam Koja dengan Metode Kontak}

a. Penyegaran

Diinokulasikan 1 ose biakan isolate Salmonella enteritidis ATCC 13067 dalam media NA ke dalam tabung reaksi yang berisi $5 \mathrm{ml}$ media LB steril kemudian dinkubasi pada suhu $37^{\circ} \mathrm{C}$ selama 24 jam. Pertumbuhan bakteri Salmonella enteritidis ATCC 13067 dapat dilihat dengan adanya kekeruhan pada media LB (Esmailnejad dkk., 2019 yang telah dimodifikasi).

b. Pembuatan Kultur Stok Salmonella enteritidis ATCC 13067

Isolat bakteri yang sudah disegarkan kemudian dibiakkan pada media NA tegak, diinkubasi dengan suhu $37^{\circ} \mathrm{C}$ selama $2 \times 24$ jam. Kultur ini tahan disimpan hingga 3 bulan dalam suhu $4^{\circ} \mathrm{C}$ (Benson, 2001). Salmonella enteritidis ATCC 13067 dari kultur stok dibiakkan lagi pada medium cair LB (Lactose Broth) dan disimpan dalam inkubator selama $1 \mathrm{x}$ 24 jam pada suhu $37^{\circ} \mathrm{C}$.

c. Uji Aktivitas Antibakteri Ekstrak Daun Salam koja dengan Metode Kontak

Kultur bakteri yang sudah diencerkan dalam LB dengan perbandingan konsentrasi $1 \mathrm{ml}$ kultur bakteri dan $9 \mathrm{ml}$ LB. Selanjutnya dipipet $1 \mathrm{ml}$ kultur untuk masingmasing bakteri ke dalam tabung mikrovial, kemudian ditambahkan $1 \mathrm{ml}$ ekstrak dengan kosentrasi sebesar $10.000 \mathrm{ppm}$ (sesuai perlakuan lama 
penyimpanan 0 hari, 3 hari, 6 hari, 9 hari, dan 12 hari). Masing-masing tabung mikrovial tadi diinkubasi dengan perlakuan waktu inkubasi 24 jam. Setelah waktu inkubasi tercapai maka sebanyak $0,1 \mathrm{ml}$ ditanam dalam media Salmonella - Shigella Agar (SSA) dengan metode sebar kemudian diinkubasi selama $24-48$ jam. Analisis hasil dilakukan dengan menghitung indeks pertumbuhan relatif $(\log \mathrm{Nt} / \log \mathrm{No})$
(Parhusip dkk., 2008 yang telah dimodifikasi).

\section{HASIL DAN PEMBAHASAN}

\section{Total Fenol}

Berdasarkan Tabel 1 terlihat bahwa ekstrak daun salam koja pada masingmasing perlakuan mengandung senyawa fenol.

Tabel 1. Hasil analisis total fenol ekstrak daun salam koja secara kualitatif dan kuantitatif

\begin{tabular}{cccc}
\hline \multirow{2}{*}{ No. } & \multirow{2}{*}{ Kode Sampel } & \multicolumn{2}{c}{ Total Fenol } \\
\cline { 3 - 4 } & & $(+/-)$ & Rata-rata $(\mathrm{mg} / 100 \mathrm{~g})$ \\
\hline 1. & P1 (hari ke-0) & Positif & $3.598,17^{\mathrm{a}}$ \\
2. & P2 (hari ke-3) & Positif & $2.677,68^{\mathrm{ab}}$ \\
3. & P3 (hari ke-6) & Positif & $1.680,91^{\mathrm{b}}$ \\
4. & P4 (hari ke-9) & Positif & $1.539,03^{\mathrm{b}}$ \\
5. & P5 (hari ke-12) & Positif & $1.104,92^{\mathrm{b}}$ \\
\hline
\end{tabular}

Keterangan: Nilai rata-rata yang diikuti huruf yang berbeda pada kolom yang sama menunjukkan pengaruh yang berbeda nyata.

Sampel yang mengandung fenol akan bereaksi dengan ion $\mathrm{FeCl}_{3}$ sehingga akan terjadi perubahan warna menjadi biru kehitaman. Menurut de-Fatima dkk (2006), daun salam koja mengandung senyawa fenol, flavonoid, fenolik, saponin, glikosida, dan sianogenik glikosida.

Menurut analisis sidik ragam (ANOVA) lama penyimpanan daun salam koja berpengaruh nyata terhadap total fenol $\mathrm{P}<0,05)$. Nilai rata-rata total fenol berkisar antara $1.104,92 \mathrm{mg} / 100 \mathrm{~g}$ hingga $3.598,17$ $\mathrm{mg} / 100 \mathrm{~g}$. Nilai terendah diperoleh pada perlakuan P5 (penyimpanan hari ke-12) yaitu sebesar 1.104,92 mg/100g. Nilai tertinggi diperoleh pada perlakuan P1 (penyimpanan hari ke-0) yaitu sebesar $3.598,17 \mathrm{mg} / 100 \mathrm{~g}$, tidak berbeda nyata dengan P2 (penyimpanan hari ke-3) dan berbeda nyata dengan perlakuan P3 (penyimpanan hari ke-6), P4 (penyimpanan hari ke-9), dan P5. Semakin lama penyimpanan daun salam koja, semakin menurun total fenol dalam daun tersebut.

Hal ini disebabkan karena sifat-sifat fenol. Menurut Sundari (2009), fenol memiliki sifat asam, mudah dioksidasi, mudah menguap, serta sensitif terhadap cahaya dan oksigen. Penurunan fenol terjadi karena sifat fenol yang mudah menguap dan mudah dioksidasi selama penyimpanan. Selama proses oksidasi senyawa fenol menurun dikarenakan oleh enzim peroksidase. Takahama (2004) menyebutkan senyawa fenol yang terakumulasi dalam vakuola sel bisa teroksidasi oleh enzim peroksidase dengan terbentuknya peroksida dalam vakuola atau di luar vakuola yang berdifusi ke dalam organel. Semakin lama penyimpanan daun salam koja maka senyawa fenol akan semakin menurun.

\section{Konfirmasi Bakteri}

Tabel 2. Uji konfirmasi Salmonella enteritidis ATCC 13067

\begin{tabular}{|c|c|}
\hline Parameter yang Diamati & Hasil \\
\hline Bentuk Koloni & Batang \\
\hline Pewarnaan Gram & Gram Negatif \\
\hline Katalase & Positif (menghasilkan gelembung) \\
\hline
\end{tabular}


Uji konfirmasi Salmonella enteritidis ATCC 13067 meliputi pengamatan bentuk koloni, pewarnaan Gram, dan uji Katalase. Hasil pengamatan uji konfirmasi $S$. enteritidis ATCC 13067 dapat dilihat pada Tabel 2. Hasil pengamatan pada mikroskop perbesaran 100x menunjukkan bentuk koloni dari S. enteritidis ATCC 13067 adalah berbentuk batang. Menurut Giannella (1996), Salmonella enteritidis merupakan bakteri yang berbentuk batang, tidak berspora, memiliki ukuran lebar antara $0,5-0,7 \mu \mathrm{m}$ dan panjang $1,0-3,0$ $\mu \mathrm{m}$, besar koloni rata-rata 2-4 $\mathrm{mm}$, dominan bergerak dengan flagel peritrik dan termasuk bakteri Gram negatif.

Hasil pengamatan mikroskopik pada kaca preparat yang berisi $10 \mu \mathrm{L}$ Salmonella enteritidis ATCC 13067 menunjukkan bahwa Salmonella enteritidis ATCC 13067 berwarna merah dan berbentuk batang. Pengujian pewarnaan gram tersebut bertujuan untuk menguji bakteri Gram negatif dan Gram positif. Salmonella enteritidis ATCC 13067 menunjukkan bahwa bakteri tersebut adalah bakteri Gram negatif. Bakteri Gram negatif dibuktikan dengan hasil pewarnaan gram berwarna merah, hal ini dikarenakan bakteri Gram negatif mempunyai dua lapisan dinding sel, yaitu lapisan luar yang tersusun dari lipopolisakarida dan protein, dan lapisan dalam yang tersusun dari peptidoglikan tetapi lebih tipis dari pada lapisan peptidoglikan pada bakteri Gram positif (Timotius, 1982).

Uji katalase yang dilakukan pada $S$. enteritidis ATCC 13067 memberi hasil positif. Hasil positif ditandai dengan adanya gelembung pada biakan yang dioleskan pada petri. Tujuan dilakukannya uji katalase adalah untuk mengetahui bakteri tersebut merupakan bakteri aerob, anaerob fakultatif, atau anaerob obligat. Bakteri yang memerlukan oksigen akan menghasilkan hidrogen peroksida $\left(\mathrm{H}_{2} \mathrm{O}_{2}\right)$ yang beracun bagi bakteri itu sendiri. Namun bakteri tetap dapat hidup dikarenakan enzim katalase yang dapat mengubah $\mathrm{H}_{2} \mathrm{O}_{2}$ menjadi $\mathrm{H}_{2} \mathrm{O}$ dan $\mathrm{O}_{2}$ (Reiner, 2013). Menurut Anon., (1993) Salmonella sp. merupakan bakteri aerob fakultatif, sehingga hasil uji katalase adalah positif. Berdasarkan uji konfirmasi di atas, bakteri yang digunakan dalam penelitian ini merupakan murni Salmonella enteritidis dan tidak terkontaminasi dengan bakteri lain. Hasil uji menunjukkan Salmonella enteritidis ATCC 13067 berbentuk batang, Gram negatif, dan katalase positif.

\section{Aktivitas Antibakteri Ekstrak Daun Salam Koja Pada Pertumbuhan Salmonella enteritidis ATCC 13067 dengan menggunakan Metode Kontak}

Tabel 3. Hasil uji aktivitas antibakteri ekstrak daun salam koja terhadap pertumbuhan $S$. enteritidis ATCC 13067

\begin{tabular}{ccccc}
\hline $\begin{array}{c}\text { Kode } \\
\text { Sampel }\end{array}$ & $\begin{array}{c}\text { Jumlah koloni } \\
\text { sebelum } \\
\text { dikontakkan (No) }\end{array}$ & $\begin{array}{c}\text { Jumlah koloni } \\
\text { setelah dikontakkan } \\
(\mathrm{Nt})\end{array}$ & $\begin{array}{c}\text { Aktivitas } \\
\text { Antibakteri } \\
\text { (Siklus Log) }\end{array}$ & $\begin{array}{c}\text { Persentase } \\
\text { Kematian }(\%)\end{array}$ \\
\hline P1 & $1,15 \times 10^{7}$ & $5,56 \times 10^{5}$ & $-1,321^{\mathrm{c}}$ & 95,16 \\
P2 & $1,15 \times 10^{7}$ & $3,03 \times 10^{6}$ & $-0,622^{\mathrm{b}}$ & 73,68 \\
P3 & $1,15 \times 10^{7}$ & $8,67 \times 10^{6}$ & $-0,131^{\mathrm{ab}}$ & 24,63 \\
P4 & $1,15 \times 10^{7}$ & $9,90 \times 10^{6}$ & $-0,065^{\mathrm{ab}}$ & 13,62 \\
P5 & $1,15 \times 10^{7}$ & $2,85 \times 10^{7}$ & $0,198^{\mathrm{a}}$ & $-148,11$ \\
\hline
\end{tabular}

Keterangan: Nilai rata-rata yang diikuti huruf yang berbeda pada kolom yang sama menunjukkan pengaruh yang berbeda nyata.

$(-)=$ terjadinya penurunan jumlah koloni

$(+)=$ terjadinya kenaikan jumlah koloni

Hasil analisis sidik ragam (ANOVA) pada Tabel 3 menunjukkan bahwa ekstrak daun salam koja selama penyimpanan berpengaruh nyata terhadap pertumbuhan $S$. enteritidis ATCC $13067 \quad(\mathrm{P}<0,05)$. Aktivitas antibakteri ekstrak daun salam koja menunjukkan kisaran aktivitas antibakteri dari 0,198 sampai -1,321 siklus 
log dan persentase kematiannya adalah dari $-148,11 \%$ sampai $95,16 \%$. Aktivitas antibakteri terendah terdapat pada perlakuan P5 yaitu penyimpanan hari ke-12 sebesar 0,198 siklus log dan menunjukkan persentase kematian bakteri sebesar $148,11 \%$ dan aktivitas antibakteri tertinggi ditunjukkan pada perlakuan P1 yaitu penyimpanan hari ke-0 sebesar -1,321 siklus log dan menunjukkan persentase kematian bakteri sebesar 95,16\%.

Semakin lama penyimpanan daun salam koja semakin menurun aktivitas antibakteri S. enteritidis ATCC 13067. Hal ini dikarenakan semakin lama penyimpanan daun salam koja semakin menurun pula total fenol yang dikandung. Salah satu antibakteri pada ekstrak daun salam koja adalah fenol, mekanisme kerja antibakteri senyawa fenol dalam membunuh bakteri yaitu dengan mendenaturasi protein sel. Ikatan hidrogen yang terbentuk antara fenol dan protein mengakibatkan struktur protein menjadi rusak. Ikatan hidrogen tersebut akan mempengaruhi permeabilitas dinding sel dan membran sitoplasma dikarenakan keduanya tersusun dari protein. Permeabilitas dinding sel dan membran sitoplasma yang terganggu dapat menyebabkan ketidakseimbangan makromolekul dan ion dalam sel, sehingga sel menjadi lisis (Pelczar dan Chan, 1988).

\section{Kesimpulan}

\section{KESIMPULAN DAN SARAN}

Berdasarkan penelitian yang telah dilakukan dapat diambil kesimpulan sebagai berikut:

1. Hasil pengujian total fenol secara kualitatif menunjukkan bahwa ekstrak daun salam koja positif mengandung senyawa fenol. Lama penyimpanan daun salam koja berpengaruh nyata terhadap total fenol dan aktivitas antibakteri pertumbuhan Salmonella enteritidis ATCC 13067.

2. Perlakuan penyimpanan daun salam koja terbaik adalah perlakuan tanpa penyimpanan karena mengandung total fenol yang sangat tinggi sebagai antibakteri sebesar 3,598 $\mathrm{g} / 100 \mathrm{~g}$ dan mampu menghambat pertumbuhan Salmonella enteritidis ATCC 13067 sebesar -1,321 siklus log atau 95,16\% kematian bakteri.

\section{Saran}

1. Diperlukan penelitian lebih lanjut mengenai aktivitas antibakteri ekstrak daun salam koja terhadap pertumbuhan bakteri patogen lain.

2. Diperlukan penelitian lebih lanjut mengenai pengaplikasian ekstrak daun salam koja ke dalam bahan pangan.

\section{DAFTAR PUSTAKA}

Anonimous. 1993. Buku Ajar Mikrobiologi Kedokteran. Binarupa Aksara, Jakarta.

Anonimous. 2018. Profil Kesehatan Indonesia Tahun 2017. Departemen Kesehatan Republik Indonesia, Jakarta.

Choudhory, P.R. dan A.N. Garg. 2007. Variation in essential, trace, and toxic elemental contents in Murraya koenigii a spice and medicinal herb from different Indian states. J. Food Chem. (104):1454-1463.

Chun, O.K., D.O. Kim, dan C.Y. Lee. 2003. Superoxide radical scavenging activity of the mayor polyphenols in fresh plums. Journal of Agricultural and Food Chemistry, i51:80678072.

de-Fatima, A., L.V. Modolo, L.S. Conegero, R.A. Pilli, C.V. Ferreira, L.K. Kohn, dan J.E. de-Carvalho. 2006. Lactones and their derivatives: biological activities, mechanisms of action and potential leads for drug design. J. Med. Chem. (13):33713384.

Del-Portillo, F.G. 2000. Moleculer and Celluler Biology of Salmonella Pathogenesis. Di dalam Cary, J.W.J.E. Linz, dan D. Bhatnagar. Microbial Foodborne Disease: 
Mechanisms of Pathogenesis and Toxin Synthesis. Techonomic Publishing Company, Inc. Cancaster, Pennsylvania, USA.

Esmailnejad, A., B. Abdi-Hachesoo, E.H. Nasab, dan M. Shakoori. 2019. Production, Purification, and Evaluation of Quail Immunoglobulin $\mathrm{Y}$ against Salmonella typhimurium and Salmonella enteritidis. Department of Pathology, School of Veterinary Medicine, Shiraz University, Iran. Molecular Immunology 107:79-83.

Fazlara, A dan M. Ekhtelat. 2012. The Disinfectant Effect of Benzalkonium Chloride on Some Important Foodborne Pathogens. AmericanEurasian Journal of Agricultural and Environment Scientifique.

Giannella, R. A. 1996. Salmonella, In: Baron's Medical Microbiology (Barron S dkk, eds.) (edisi ke-4th ed.). Univ of Texas Medical Branch. (via NCBI Bookshelf) ISBN 09631172-1-1.

Harborne, J.B. 1987. Metode Fitokimia: Penuntun Cara Modern Menganalisa Tumbuhan. Terbitan Kedua. Terjemahan Kosasih Padmawinata dan Iwang Soediro. Institut Teknik Bandung. Bandung.

Harrigan, W.F., dan M.E. Mc Chance. 1998. Laboratory Methods in Food Microbiology 3rd edition.Academic Press, Inc., New York.

Juniarhati, P.E. 2011. Skrining Bakteri Asam Laktat Isolat Susu Sapi Bali Penghasil Bakteriosin Penghambat Bakteri Patogen E.coli Penyebab Diare Akut. Skripsi. Jurusan Farmasi, Unversitas Udayana, Bali.

Mrmosanin, J.M., A.N. Pavlovic, dan J.N. Veljkovic. 2015. The Effect of Storage Temperature and Thermal Processing on Cathecins, Procyanidins, and Total Flavonoid Stability in Commercially Available Cocoa Powder. Physics,
Chemistry and Technology Vol. 13 No. 1

Parhusip, A. J. N., M. T. D. Ambarita, dan L. Thresia. 2008. Kajian Metode Ekstraksi Antimikroba Cabai Jawa (Piper retrofractum Vahl.) Kering Terhadap Mikroba Patogen Pangan. Jurnal Ilmu dan teknologi Pangan Vol. 6, No.1, April 2008.

Pelczar, M. J., dan E. C. S., Chan. 1988. Dasar-Dasar Mikrobiologi. Universitas Indonesia Press, Jakarta.

Reiner, K. 2013. Catalase Test Protocol. American Society for Microbiology.

Siswandono dan B. Soekardjo. 1995. Kimia Medisinal. 28-29. 157. Airlangga University Press, Surabaya.

Sudarwanto, M., Rastina, dan I. Wientaris. 2015. Aktivitas Antibakteri ekstrak Etanol Daun kari (Murraya koenigii) Terhadap Staphylacoccus aureus, Escherichia coli, dan Pseudomonas sp. Jurnal Kedokteran Hewan. Halaman 185

Sundari, Dian. 2009. Toksisitas Akut (LD50) dan Uji Gelagat Ekstrak Daun Teh Hijau (Camellia sinensis) Pada Mencit. Jurnal Media Penelitian dan Pengembangan Kesehatan. Vol XIX. No 4. Hal : 198-203.

Takahama, U. 2004. Oxidation of vacuolar and apoplastic phenolic substrates by peroxidase: physiological significance of the oxidation reactions. Phytochemistry Reviews. 3(1-2):207-219

Tiwari, Kumar, K.Mandeep, K.Gurpreet dan K. Harleem. 2011. Phytochemical Screening and Extraction: A Review. Internasionale Pharmacuetica Sciencia Vol. 1: issue 1.

Timotius, K.H. 1982. Mikrobiologi Dasar. Cetakan I. UKSW, Salatiga.

Widnyani, I. A. P. A. 2014. Daya Hambat Ekstrak Daun Kemangi (Ocimum 
sanctum) Terhadap Pertumbuhan Eschericia coli, Salmonella enteritidis, dan Listeria monocytogenes. Skripsi. Tidak dipublikasikan. Jurusan Teknologi Industri Pertanian, Universitas Udayana, Bali. 